\title{
Anatomizing the Human Body in the Training Elementary School: Experience Report of the University Extension of Undergraduate Nursing Students
}

\section{Vinicius Do Carmo Borges Silva*1, Dathynara Da Silva Alves ${ }^{1}$, Brenda Rainara Pereira Da Silva ${ }^{1}$, Júlia Maria De Jesus Sousa ${ }^{1}$, Luisa Chrisdayla Macêdo Santos ${ }^{1}$, Gleibson Moura Ferreira ${ }^{2}$, Giovanna De Oliveira Libório Dourado ${ }^{3}$, Lílian Machado Vilarinho De Morae ${ }^{3}$ and Jailson Alberto Rodrigues ${ }^{3}$}

${ }^{1}$ Nursing Program (CGBENF), Campus Amilcar Ferreira Sobral (CAFS) of the Federal University of Piaui (UFPI), Brazil

2Urgency and Emergency Department, UFPI/CAFS, Brazil

${ }^{3}$ Adjunct Professor I do CGBENF/CAFs/UFPI, Brazil

${ }^{*}$ Corresponding author: Do Carmo Borges Silva V, Undergraduate Student in Nursing Bachelor's Degree (CGBENF) Campus Amilcar Ferreira Sobral (CAFS) of the Federal University of Piaui (UFPI), Brazil, Tel: +55 (86) 215 5625; Fax: +55 (86) 3215-5594; E-mail: viniciusdocarmo1@hotmail.com

Received date: September 30, 2019; Accepted date: December 13, 2019; Published date: December 20, 2019

Citation: Silva VCB, Alves DD, Da Silva BRP, Sousa DJM, Macêdo-Santos LC, et al. (2019) Anatomizing the Human Body in the Training Elementary School: Experience Report of the University Extension of Undergraduate Nursing Students. Arch Med Vol: 11 Iss: 3:2

Copyright: (C2019 Silva VCB, et al. This is an open-access article distributed under the terms of the Creative Commons Attribution License, which permits unrestricted use, distribution, and reproduction in any medium, provided the original author and source are credited.

\section{Abstract}

Background: Human anatomy is the science that studies the shape of the human body, being charged with naming and describing its constituent structures at the macro level and Microscopic. The view of This, the project "anatomizing" The human body and its functioning in the process of training in elementary education seeks to contribute in the elaboration of teaching plans, selection of materials and approach of themes to be, possibly, used in all room.

Methods: The workshops performed by the students of the nursing course of the Federal University of Piauí occurred during the times of the discipline teaching of sciences/biology of a municipal school of Floriano-Piauí. Were used Resources as data-Shows, Bookcases illustrative elaborated by the project members and macro anatomical molds for the realization of the project. Yet, the Students visited the Lab of Macroscopic and Microscopy Human Anatomy of CAFS.

Findings and Conclusion: Dynamics performed during the workshops showed that after the end of the project the students expressed a great obtaining of the knowledge addressed during the interactive class and interest in higher education focused on the area of Cheers.

Keywords: Anatomy; Elementary School; Workshops Project Extension; Nursing students

\section{Introduction}

Human anatomy is the science that studies the shape of the human body, being charged with naming and describing its constituent structures at the macro level and Microscopic. The same consists of a theoretical and practical study, where the theory consists of explaining concepts about the functionalities of the body, both in the classroom and in laboratories [1].

The incomprehension of the human body influences not only on everyday issues, but also on the evolution of life. Since the basic sciences' ends are essential to enable the student to recognize the human body as an integrated system.

According to Cerri et al. [2], the study of anatomy oriented in schools is incomplete, since there are no laboratories in these places. In this perspective, the didactic books become the main tool for studying the human body. However, it was found inadequate nomenclature and low-quality images in these books, thus damaging the teaching.

The view of this, the project "anatomizing" the human body and its functioning in the process of training in elementary education seeks to contribute in the elaboration of teaching plans, selection of materials and thematic approach to be used in the classroom. So that the classes are more interactive, with exposure of models and anatomical pieces showing the human body and demonstrating systems, organs and functions, sharpen the curiosity and creating an information base, which enhances complementary learning from higher to elementary education.

Therefore, anatomizing guides students on the implantation of the anatomical study in the discipline of Applied Sciences in elementary school, in order to instigate the search for knowledge, even if in a succinct manner, to the students and in 
such a way that they understand more accurately the human body structure and its functionalities from education of fundamental importance. With this, a team of undergraduates was selected to interview students of the eighth year of elementary school in a municipal college located in FlorianoPiauí, Brazil, and they verified how their understanding of the anatomy of the human body is known.

\section{Materials and Methods}

A sort was made to select the teaching institutions in which the project would be carried out. The sorting of the schools happened in a simple random way, through an operationalized tool in the Excel for Windows program. Each school was assigned a probability between zero (0.0) and one (1.0). Those where they had the highest probability were the ones selected then, authorization was requested to the direction of each school to carry out the proposal, after the appropriate clarifications and performances, they issued a letter of consent in order to accept the partnership.

The project was developed in the school field of the municipality of FLORIANO-PI, of these schools, one of the private teaching network, and another of the public teaching network of which offer classes from the fifth (5th) to the Ninth (9th) year of major elementary education, were selected to compose the framework of schools.

All students from these classes in the selected schools received free and informed consent terms so that their parents would allow the participation of these students in the project's actions. Also, their respective professors of the science discipline, signed terms confirming their participation. The proposal was carried out in operational stages, which aimed to invest action and adapt to reality, establish concepts, identify potentialities, improve skills, build knowledge and disseminate information.

Bachelor nursing degree students were selected, who had already attended the discipline of Human Anatomy, who studied between the 4th and 8th periods of the course. Besides these, all the students of the discipline human anatomy offered by the nursing course of the Campus Amílcar Ferreira Sobral - CAFS, from the semester 2018.2 had voluntary participation in order to guarantee the project activities. What was counted as a formative note in the discipline?

The stage of authorization and division of groups occurred during the month of November of 2018 in which monthly meetings occurred for Discussion of the theory, the planning, and the realization of the project and the problematization of the possible situations that the intervention teams could encounter.

These groups corresponded to the intervention teams, the Logistic team, and the team of analysis of Data, the Logistic team was formed by other students who did not participate of the intervention teams. Then, the previous contact with the schools was established by the logistic team, who required permission from the schools' principals in order to enhance the project, clarify doubts, request and take to schools the necessary materials necessary for the workshops.

Before the workshops (intervention), questionnaires were applied to the students and teachers. They aimed to probe the reality. These questionnaires were composed of objective and subjective questions, self-applied; respondents had up to ten (10) minutes during the class to answer them. Each questionnaire contained an individual code for each participant (teachers and students), to keep the Anonymity.

The first contact with the targeted audience, in the school, happened during the Biology/Science classes. This phase worked as a guideline for the planning of the workshops and selection of content that would be approached by the intervention groups. Then, the data analysis team managed the questionnaires applied to students and teachers, and subsequently gave descriptive and inferential statistical treatment to these questionnaires.

Subsequently, the intervention team initiated the phase of joint knowledge production (interventions), and was responsible for the development of the workshops of production/sharing of knowledge and practices, and this happened 2 times a month in each school selected and for each series, the day and time was determined by the school's direction, along with the Logistic team.

The workshops took place during the times of the Discipline teaching science/biology and occupied the entire time of the class. Resources were used as data-shows, illustrative bookcases elaborated by the project members and macro anatomical molds for the realization of the project. The students still made a visit to the laboratory of macroscopic human anatomy and microscopy Laboratory of CAFS.

\section{Results}

Among the focuses of the project ' Anatomizing ', offer to elementary education the Superior, stimulating mutual advantage and collaboration in academic and fundamental education-to the knowledge of the human body and its functioning, giving the students of course of Undergraduate nursing at the Almicar Ferreira Sobral Campus-CGBENF/CAFS The opportunity to know the world of teaching, as teachers in development.

The theoretical view of the school is to provide quality education, with innovative educational methods, keeping teachers able to form and care for the student as a member of the school and thus be recognized by society as an institution of excellence. Thus, the anatomizing project enters with an active methodology that assists the students on their performance and understanding of the human body, so that they may be able to reflect and guide himself until they find themselves a solution or questioning of something abnormal in their own body.

Your school mission: to guarantee the student an education that assigns skills, offering a community-accessible education and providing the conditions for meaningful, up-to-date and effective learning, capable of preparing competent students 
and with solid argumentation. Along with the mission of the project, expose the students to a content about anatomy which they do not currently student on elementary school, and may develop interest not only as an elementary school student, but possible future practitioner.

The school has: one steering room, one coordinating, three specialized educational service, an administrative support room, a teacher's room, twenty-two classrooms, a library, secretariat, sports court, auditorium, an office, storeroom, a pantry, canteen, a cafeteria, 1 of the 5 bathrooms, a deposit, an elevator and a bathroom for disabled people. However, not all the areas above work. For example, the elevator works as a garbage disposal and the library that was made by adapting a classroom.

There are classrooms with broken doors or even without them. Bathroom without floor and water dusty, without the minimum hygiene needed for students and staff. Bumpy roof Only one room has air conditioning and is about the board. On the Upper Floor, the hardwood floors are poorly placed in place. The walls of the halls were scratched and vandalized. The rooms have a lower number of chairs than the quantity of students, moreover the blackboards are dirty and scribbled, making the work difficult. This is a precarious situation, originating from scrapping and inconstant governments in the present city, including traces of corruption and neglect with municipal Education, which affects students who need teaching obtaining better life. Though the difficulties, the project raises bring interest of higher education, such as in healthcare area, providing them with experiences that the school cannot offer.

The municipal school is wide, in its social sense, receiving students to educate children and elementary school, coming from nearby neighborhoods, distant and some rural areas. Another factor to be cited is that the school has no anatomy lab and no other modalities of teaching focused on other disciplines, which decreases the interest of students on other subjects. Therefore, classes like anatomy become more attractive to the young man's gaze with physical illustrations and interactive activities than just reading in the book and seeing images of how it could be a piece or Anatomical region. On the other hand, the school has textbooks and data show to try to provide diversified classes.

In a second moment of the project actions in the school. After applying the questionnaire to investigate the level of knowledge of students with relation to anatomy, we identified aspects that can be observed in the following speech:

What have you ever studied about the human body?

\section{\{Class A\}}

"Respiratory, pulmonary, urinary system" (student A) "systemic and pulmonary sirculation, heart and Skin" (student e)

\section{\{Class B}

"Heart: cardiovascular, lung: respiratory, bladder: Urinary" (pupil C)
"The organs, the bones, the cells, the diseases..." (Student $\mathrm{H}$ )

It is perceived that students experience a superficial knowledge about the teaching of the anatomy due to the neglect of the Government towards the school and its teaching professionals, causing the education to suffer precariousness. Situation is that can be visible in several institutions of teaching distributed by Brazil, forming future citizens uninformed and uninterested in knowledge - Corresponding to government Resources denied to schools and family influences with low teaching instructions-being easy targets for manipulation and control by the Governmental, and Media. Beyond the Presence of teachers who do not have an interest and preparation for teaching students through student development resulting in the present deficit in education and learning.

Then, a third occasion to return to school, now with classes aimed at the student public in two modalities, practice and theoretical. It was presented a class about the human reproductive system, through mockups and slides, at a theoretical moment. In the practice class, the students visited the morph functional and microscopy Laboratories of the Federal University of Piaui, where they could obtain preparation of animal tissues in histological slides, anatomical macro molds and realistic parts.

Their teaching material is just a book of general Biology, in which science is approached in a broad and generalized way, without emphasis on the anatomy itself and/or the human body. This fact, which corroborates the deficit on the part of the students on the subject approached.

When analyzed through the questionnaires applied, the level of disability of young people. During so many questions, which came out during the expository class, it was done what was within reach for students to understand and to make the most of their doubts. That occurred because they possess a simple material and do not have access to complete information, there was a beginning impasse for students to get involved and enjoy the project.

The teacher had a collaborative interaction with the class. Despite the subject not being part of the curriculum of the students, she allowed the team to accomplish the project and endorsed with total freedom for the activities to be performed. In this perspective, her contribution to the Activity was the role of facilitator, in the organized way. However, she could also have stimulated the participation of students and report important points of the subject to assist in their Pedagogical plan, once she has a degree in biological sciences which provides her full preparation for contributions to the part.

\section{Discussion}

The present work was elaborated and applied through two stages, being divided into: Questionnaire and workshops. In the first moment, the deficiency of knowledge of the young people in relation to the systems of the human body was evident, the questionnaires were executed with subjective 
questions such as: "What do you know about the human body?", "To you, what is the human body?" and "Do you know why the human body is divided into systems? If so, why?". Through questions such as these, the lack of knowledge of students in public schools was found in relation to applied sciences learning.

For Navarro et al. [3], the space outside schools influences a lot in the incentive to learn students, thus intensifying the interest in the study and developing their cognitive and motor skills. In this perspective, once it is badly structured, it facilitates the failure and discouraging of these students.

Among the negative aspects that are present in the school where the 'anatomizing' project was presented, it can be highlighted that the lack of methodological structure and tools is one of the greatest influence for the lack of interest in studies and life goals, personal problems and lack of family inspirations that contribute to discourage student. Some students cited that parents had no higher education and that they as future young people from Brazil intended to work only and not to pursue an academic career.

A study by Almeida and Fernandes [4] shows that students and a public school in the interior of São Paulo responded mediating to questionnaires that attend schools only to possess a diploma and try the Enem (National High School examination) but that for them the School of Dreams is a school with good structure for activities aimed at sports practice and entertainment activities.

In the other hand of all this is the present school where there are no laboratories focused on biological sciences, offering only one illustrated book generating in the student a sensation that is not important and superficial such subject addressed now.

The practice stage of the project, which consisting on bringing the students to the laboratories of the Federal University of Piauí, it was possible to show them how the higher education is interesting and attractive, raising their interest and dream of joining higher education.

During their experiment between schools that use active technologies and methodologies. Borges and Fleith [5] highlighted that the results of schools that do not use them, in their practices did not have differences in the question of learning of students, by only evidencing that girls had a better commitment than boys.

However, the students' participation in the project 'anatomizing' the use of active methodologies was made very receptive and accepted in relation to the learning and understanding of the subject for the students, making them paying more attention and involvement with the approached topic, showing that this sort of classes is absent in their daily lives, evidencing that if they experienced different classes they could be more interested in the study, which they do not face due to its restriction.

The school architecture has a huge importance for the comfort of teaching and motivating teachers of education, harmony in school management and incentives with methodological objectives which facilitates the performance of students, affirming that there is a clear evidence that infrastructure investments produce positive effects on learning [6].

Albernaz et al. [7] concludes that the performance of students is also affected by their socioeconomic status. However, this situation was not experienced in the present institution where the project was carried out, since the School teacher knows the Conditions that many of his pupils live and how college has a low quality structure, she faces a tough position to apply an active and different methodology in class, developing even a discouragement in teaching that ends up being transmitted to students.

In this way it is hoped that she will see the interest of the students with the project, who may be interested in changing and trying something new with them, showing even with their obstacles, that students can and manage to have a life goal and be future professionals.

\section{Conclusion and Final Considerations}

It was verified the great need for a better theoretical and practical approach to the contents dealing with the teaching of the systems of the body in order to provide a better quality in the education of students and thus certify that their rights are assured and that they can build their knowledge in a dignified manner.

It is evident the interest expressed by students in experiencing a more qualified education, but the daily situations experienced by them end up discoursing them quite a lot.

It is possible to note the lack of organization by the school administration, guaranteeing an improvement in the quality of the learning process of students from the implementation in the teaching of anatomy in disciplines addressing this theme, such as science, biology and Physical Education.

It is visible how much the public school has countless limitations in teaching and some situations that directly or indirectly are associated with student learning and that need improvements to stimulate the learning process of students by applying changes in the practices and methodology of teaching, training teachers to administer disciplines of their competence.

Thus, the project was accomplished, and it was achieved the objective of bringing knowledge acquired by the nursing students in the course of the lessons of discipline of human anatomy to students of public elementary education.

The experience of the project was extremely important for the teaching-learning process among the students of the Bachelor's degree in Nursing and the other participating students who contributed satisfactorily to the academic achievement of the mediators.

The 'anatomizing' brought the application of different methodologies in the teaching of human anatomy, which stimulated an improvement in the strategies used by 
educators in the way of addressing the contents to be provided by them.

Dynamics performed during the workshops showed that after the end of the project the students expressed a great achievement of the knowledge approached during the interactive class.

In some situations, such as the graduation of educators at educational institutions, it is necessary to apply significant changes, such as: obtaining anatomical pieces, active methodologies that stimulate the interaction of teachers with students and professional ethics, in other words, there must be a set of available equipment in the reach in search of a better apprehension of the contents. However, the project succeeded in achieving its goals and contributed positively to a mutual learning, since It allowed the experience of exposing a little about human anatomy to the students of the Bachelor of Nursing course-Campus Amílcar Ferreira Sobral and also provided an enrichment to the learning acquired by the other participating students who have distributed positively making the workshops more interactive and dynamic through the exposition of their knowledge and doubts.

\section{References}

1. De Araújo Baptista VI, De Medeiros Lima J, De Almeida Medeiros LM, Scardua A, Da Silva Baptista J (2015) Concepções sobre anatomia humana de alunos do ensino médio da cidade de Cuité-PB: funções e relações com cotidiano. Revista Brasileira de Pesquisa em Educação em Ciências 15: 59-78.

2. Cerri BR, Hoffmann JS, Rocha LC, Amorim LA, Rabelo TM, et al. (2015) Projeto de extensão: anatomia humana para os ensinos fundamental e médio. In: Congresso de extensão universitária da UNESP. Universidade Estadual Paulista (UNESP) p: 1-6.

3. Navarro L, Gervai S, Nakayama A, Prado ADS (2016) A dificuldade de aprendizagem e o fracasso escolar. Journal of Research in Special Educational Needs 16: 46-50.

4. Almeida MB, Fernandes HL (2016) O que motiva os alunos a frequentarem a escola? Revista Tecné, Episteme y Didaxis.

5. Borges CN, Fleith DDS (2018) Use of technology in teaching practice: Influence on elementary school students' creativity and motivation. Psicologia: Teoria e Pesquisa p. 34.

6. Silva FL, Muzardo FT (2016) Estudo exploratório sobre o espaço escolar: a percepção de professores de escolas públicas. Revista Thema 13: 65-78.

7. Albernaz A, Ferreira FH, Franco C (2002) Qualidade e equidade na educação fundamental brasileira. In: Pesquisa e Planejamento Econômico 32: 3. 